\title{
Faktor - faktor yang mempengaruhi migrasi masuk di Kota Jambi (studi kasus etnis Jawa di Kelurahan Buluran Kenali)
}

\author{
*Sulung Tino Anggara; Junaidi; Yulmardi
}

Prodi Ekonomi Pembangunan, Fakultas Ekonomi dan Bisnis, Universitas Jambi

*E-mail korespondensi: Sulungtinoanggara@yahoo.com

\begin{abstract}
Research objectives: 1) To determine the characteristics of Javanese ethnic groups in Buluran Kenali Village; 2) To find out and analyze the influence of age, origin, education level and length of stay on the income of Javanese ethnic migrant residents in the Buluran Kenali Village. The data used in this study are primary data obtained from survey results by distributing questionnaires and interviews. The analytical method used in this study is descriptive and quantitative analysis methods, using multiple linear regression analysis. The results of this study indicates that the average age of migrants is 44 years old, married with a total of 2 people, education that has completed an average of 10 years comes directly from Java, with the reason of moving to Jambi City due to family invitation and knowing the City Jambi from family/friends. From the results of multiple linear regression it is known that age, origin, level of education, length of stay have an effect on and significantly affect the income of ethnic Javanese migrants in Jambi City. Partially, age, education and length of stay influence and significantly affect the income of Javanese ethnic migrants in Jambi City, while the origin does not affect and the income of ethnic Javanese migrants in Jambi City.
\end{abstract}

Keywords: Migration, Income, Age, Origin, Education Level, Length of Stay.

\begin{abstract}
Abstrak
Tujuan penelitian: 1) Untuk mengetahui karakteristik penduduk etnis Jawa di Kelurahan Buluran Kenali; 2) Untuk mengetahui dan menganalisis pengaruh umur, asal, tingkat pendidikan dan lama tinggal terhadap pendapatan penduduk migran etnis Jawa di Kelurahan Buluran Kenali. Data yang digunakan dalam penelitian ini adalah data primer yang diperoleh dari hasil survey dengan cara menyebarkan kuisioner dan wawancara. Metode analisis yang digunakan dalam penelitian ini adalah metode analisis deskriptif dan kuantitatif, dengan menggunakan analisis regresi linier berganda. Hasil penelitian ini menunjukkan bahwa rata-rata umur migran adalah 44 tahun, berstatus kawin dengan jumlah tanggungan 2 orang, pendidikan yang berhasil ditamatkan rata-rata 10 tahun, berasal langsung dari Pulau Jawa, dengan alasan pindah ke Kota Jambi dikarenakan ajakan keluarga dan mengetahui Kota Jambi dari keluarga/teman. Dari hasil regresi linier berganda diketahui bahwa umur, asal, tingkat pendidikan, lama tinggal berpengaruh dan signifikan terhadap pendapatan penduduk migran etnis Jawa di Kota Jambi, sedangkan daerah asal tidak berpengaruh terhadap pendapatan para migran. Secara parsial, umur, pendidikan dan lama tinggal berpengaruh dan signifikan terhadap pendapatan migran etnis Jawa di Kota Jambi, sedangkan asal tidak berpengaruh dan terhadap pendapatan migran etnis Jawa di Kota Jambi.
\end{abstract}

Kata Kunci: Migrasi, Pendapatan, Umur, Asal, Tingkat Pendidikan, Lama Tinggal. 


\section{PENDAHULUAN}

Perpindahan penduduk dari daerah asal ke daerah tujuan menjadi salah satu bagian dari proses pembanguanan. Aktivitas perpindahan penduduk dari daerah asal ke daerah tujuan merupakan salah satu proses penyebab pertumbuhan penduduk, disamping penyebab lain seperti pertumbuhan alamiah penduduk yaitu kelahiran (fertilitas) dan kematian (mortalitas), perluasan wilayah, maupun perubahan status wilayah dari daerah pedesaan menjadi daerah perkotaan (Munir, 2000: 115).

Motivasi pertama orang melakukan migrasi adalah motif ekonomi. Kondisi sosial-ekonomi di daerah asal yang tidak memungkinkan untuk memenuhi kebutuhan seseorang menyebabkan proses migrasi (Lee, 1992). Migrasi yang didasarkan pada motif ekonomi tersebut merupakan migrasi yang direncanakan oleh individu sendiri secara sukarela. Salah satu permasalahan pertumbuhan penduduk adalah tidak disertai dengan peningkatan jaminan kehidupan bagi penduduk dan penyediaan lapangan pekerjaan yang memadai di suatu daerah hal itu yang akan menyebabkan terjadinya perpindahan penduduk ke suatu daerah dengan harapan mendapatkan penghasilan yang lebih tinggi dan sumber penghidupan yang layak dari daerah asalnya (Todaro dalam Venti Septiani, 2016).

Kota Jambi juga menjadi daerah tujuan oleh para migran, khususnya etnis Jawa. Jumlah penduduk etnis Jawa mencapai $27,61 \%$ dari jumlah penduduk Kota Jambi, dengan mudah kita dapat menemukan paguyuban-paguyuban etnis Jawa di Kota Jambi, dimana kita ketahui Pulau Jawa sebagai asal penduduk etnis Jawa sudah sangat padat, oleh sebab itu mereka yang tidak memiliki kemampuan lebih akan sangat sulit untuk bersaing, dan membuat mereka memutuskan untuk mencari tempat yang baru.

Menurut data (Kota Jambi Dalam Angka, 2018) kepadatan penduduk per kabupaten/kota di Provinsi Jambi, Kota Jambi menempati urutan teratas kepadatan penduduk di Provinsi Jambi dengan kepadatan penduduk sebesar 2.588,99 jiwa/km, dimana ini berarti $1 \mathrm{~km}$ persegi pemukiman terdapat 2.588,99 jiwa penduduk. Menurut data (BPS, 2010), migrasi masuk di Kota Jambi pada tahun 2000 sebesar 566.153 jiwa sedangkan sepuluh tahun setelahnya yaitu tahun 2010 mengalami peningkatan yaitu sebesar 738.961 jiwa dan pada tahun 2015 mengalami penurunan yaitu sebesar 710.428 jiwa. Sebagaimana karakter ibukota Provinsi pada umumnya yaitu sebagai pusat pemerintahan, industri dan perdagangan. Dilihat dari sisi laju pertumbuhan selama sepuluh tahun terakhir (2000-2010) Kota Jambi sebesar 2,55 persen lebih tinggi dari pertumbuhan penduduk nasional sebesar (1,49\%) (BPS, 2017).

Faktor ekonomi menjadi pendorong utama masyarakat untuk melakukan migrasi, sementara itu dilihat dari sisi ekonomi, pertumbuhan ekonomi di Kota Jambi yang terus meningkat dari tahun 2005 hingga 2015, pada tahun 2005 pertumbuhan ekonomi Jambi ialah 7,16\% mengalami kenaikan 1,23\% dari tahun sebelumnya, namun pada tahun 2010 menalami penurunan sebesar 1,02\% menjadi 6,14\%. Pada tahun selanjutnya yaitu 2015 sebesar 5,83\% (Kota Jambi Dalam Angka, 2015).

Khususnya di Kelurahan Buluran Kenali, Kecamatan Telanaipura, Kota Jambi tidak sedikit penduduk etnis Jawa, disetiap keramaian selalu terdengar ada yang berbicara dengan bahasa jawa, sebagai pendatang mereka tidak segan untuk berbicara dengan bahasa mereka, hal itu menunjukan telah banyak orang yang menggunakan bahasa itu yang berarti penduduk etnis Jawa di Kota Jambi sudah banyak, paguyubanpaguyuban etnis Jawa sudah sangat ditemukan, seperti arisan yang semua pesertanya adalah etnis Jawa.

Berdasarkan masalah yang telah dipaparkan maka tujuan penelitian ini adalah: 1) mengetahui karakteristik penduduk migran etnis Jawa di Kota Jambi; 2) mengetahui 
pengaruh umur, asal, tingkat pendidikn, lama tinggal terhadap pendapatan penduduk migran etnis Jawa di Kota Jambi.

METODE

Penelitian ini menggunakan data primer diperoleh dengan cara melakukan observasi dan wawancara langsung dengan mengajukan pertanyaan-pertanyaan yang telah terpola dan tersetruktur seperti umur, tempat tanggal lahir, alasan menetap di Kota Jambi, pendidikan terakhir, mengetahui Kota Jambi, pendapatan kepada objek penelitian atau responden. Responden yang dimaksud adalah penduduk migran etnis Jawa di Kota Jambi.

\section{Populasi}

Populasi dapat didefinisikan sebagai suatu kumpulan dari subjek penelitian yang memiliki kualitas dan karakteristik tertentu (Andri Pratama, 2018). Populasi yang dimaksud dalam penelitian ini adalah penduduk migran etnis Jawa yang terdapat di Kota Jambi.

\section{Penentuan Sampel}

Cara penentuan sampel dilakukan dengan metode snowball sampling dengan multiple entry. Ditetapkan entry sebanyak 5 responden, selanjutnya dari responden yang dijadikan entry ini ditentukan responden yang lain dengan cara menanyakan kepada responden tersebut penduduk migran etnis Jawa lainya yang dikenal. Jumlah sampel yang diambil sebanyak 50 orang (Amri, Junaidi, dan Yulmardi, 2009).

\section{Analisis Deskriftif}

Analisis Deskriptif adalah metode analisis yang digunakan untuk mendeskripsikan fenomena-fenomena dan fakta dari karakteristik responden, seperti: umur, asal, pendidikan, lama tinggal dan pendapatan dengan peralatan statistik sederhana dan alat analisis berbasis teori.

\section{Analisis Kuantitatif}

Metode analisis kuantitatif digunakan untuk menganalisa informasi data kuantitatif melalui estimasi model regresi berganda. Adapun persamaan model regresi berganda tersebut adalah (Suharyadi dan Purwanto, 2011):

$\mathrm{Y}=\alpha+\beta_{1} \mathrm{X}_{1}+\beta_{2} \mathrm{X}_{2}+\beta_{3} \mathrm{X}_{3}+\ldots+\beta_{\mathrm{k}} \mathrm{X}_{\mathrm{k}}+\mu$

Model regresi linier berganda diformulasikan dalam penelitian ini sebagai berikut:

$\mathrm{P}=\alpha+\beta_{1} \mathrm{U}+\beta_{2} \mathrm{Da}+\beta_{3} \mathrm{Dk} 1+\beta_{4} \mathrm{Dk} 2+\beta_{5} \mathrm{LT}+\mu$

\section{Keterangan:}

\begin{tabular}{|c|c|}
\hline$P$ & $=$ Pendapatan \\
\hline 作 & $=$ Konstanta \\
\hline$\beta_{1}, \beta_{2}, \beta_{3}, \beta_{4}$ & $=$ Koefisien regresi \\
\hline $\mathrm{U}$ & $=$ Umur (tahun) \\
\hline $\mathrm{Da}$ & $=$ Dummy untuk Asal \\
\hline $\begin{array}{l}1= \\
0=\end{array}$ & $\begin{array}{l}\text { pulau Jawa } \\
\text { pulau Jawa }\end{array}$ \\
\hline $1=$ & $\begin{array}{l}=\text { Dummy untuk pendidikan } \\
\mathrm{P}\end{array}$ \\
\hline
\end{tabular}




$$
0=\text { Lainnya }
$$

Dk2 = Dummy untuk pendidikan

$$
1=\text { SLTA }
$$

$0=$ Lainnya

LT

$$
\text { = Lama Tinggal (tahun) }
$$

\section{Uji Hipotesis Secara Parsial (Uji F)}

Uji $\mathrm{F}$ digunakan untuk mengetahui signifikan atau tidaknya pengaruh variabel $\mathrm{X}_{1}$ umur migran, $\mathrm{X}_{2}$ Asal, $\mathrm{X}_{3}$ tingkat pendidikan, $\mathrm{X}_{4}$ lama tinggal secara bersama-sama simultan terhadap variabel $\mathrm{Y}$ pendapatan. Nilai $\mathrm{F}$ hitung diperoleh menggunakan formulasi:

$$
F h=\frac{R^{2} /(k-1)}{(1-R 2) /(n-k)}
$$

Dimana:

$\mathrm{Fh}=\mathrm{F}$ hitung

$\mathrm{R}^{2}=$ Koefisien determinasi

$\mathrm{k}=$ Jumlah variabel independent

$\mathrm{n}$ = Jumlah sampel

Nilai $\mathrm{F}$ hitung yang didapat selanjutnya dibandingkan dengan nilai alfa $(\alpha)$ pada derajat kebebasan $(0,05)$ dan tingkat keyakinan $95 \%$ dengan keputusan sebagai berikut:

F hitung $>$ dari nilai signifikansi $(\alpha=0,05)$ maka $\mathrm{H}_{0}$ ditolak.

F hitung $<$ dari nilai signifikansi $(\alpha=0,05)$ maka $\mathrm{H}_{0}$ diterima.

\section{Uji Hipotesis Secara Parsial (Uji T)}

Uji $\mathrm{T}$ dimaksudkan untuk mengetahui seberapa besar pengaruh tingkat signifikan variabel independent terhadap variabel dependent secara parsial dengan menggunakan formulasi:

$T=\frac{b^{2}}{s_{e}\left(b^{2}\right)}$

Dimana:

$\mathrm{T}=$ Nilai $\mathrm{T}$ hitung

$b^{2}=$ Koefisien regresi hasil estimasi

$\mathrm{Se}=$ Simpangan baku standar error

Jika t-hitung lebih kecil dari nilai signifikansi $(\alpha=0,05)$ maka hubungan antara variabel independent dan variabel dependent adalah signifikan. Hipotesa dalan uji analisis secara parsial (uji t) adalah sebagai berikut:

t hitung $>$ dari nilai signifikansi $(\alpha=0,05)$ maka $\mathrm{H}_{0}$ ditolak.

t hitung $<$ dari nilai signifikansi $(\alpha=0,05)$ maka $\mathrm{H}_{0}$ diterima.

\section{Koefisien Determinasi}

Koefisien determinasi $\left(\mathrm{R}^{2}\right)$ digunakan untuk mengetahui kerataan pengaruh antara variabel independent dengan variabel dependent. Perhitungan koefisien determinan tersebut menggunakan formulasi sebagai berikut:

$\mathrm{R}^{2}=1-\frac{E i^{2}}{Y i^{2}}$ 
Dimana:

$\mathrm{R}^{2} \quad=$ Koefisien determinan

$\mathrm{Ei}^{2} \quad=$ Observasi respon

$\mathrm{Yi}^{2} \quad=$ Ramalan respon

Nilai $\mathrm{R}^{2}$ ini antara 0-1 $\left(0<\mathrm{R}^{2}<1\right)$, semakin mendekati 1 maka nilai $\mathrm{R}$ tersebut semakin baik, berarti terdapat hubungan yang kuat antara variabel indepedent dengan variabel dependent.

\section{HASIL DAN PEMBAHASAN}

\section{Karakteristik penduduk migran masuk etnis Jawa yang berada di Kelurahan} Buluran

Deskriptif kondisi sosial ekonomi digunakan untuk menggambarkan karekteristik penduduk etnis jawa di Kota Jambi keadaan atau kondisi responden yang dapat memberikan informasi tambahan untuk memahami hasil penelitian. Penyajian data deskriptif dalam penelitaian ini bertujuan agar dapat dilihat profil dari data keadaan sosial etnis jawa yang digunakan dalam penelitian.

\section{Umur}

Umur merupakan hal yang penting bagi kehidupan manusia, karena sebagai batasan kemampuan untuk melakukan kegiatan dalam kehidupannya dan tinggi rendahnya umur menentukan kapan seseorang dapat bekerja. Umur juga merupakan modal dasar dalam kehidupan, dalam banyak jenis pekerjaan standar usia menjadi syarat penerimaan dan menjadi batas bagi seseorang untuk bekerja, berhenti dari pekerjaan oleh karena faktor umur yang tidak memungkinkan lagi untuk bekerja. Oleh karena itu perbedaan umur seseorang juga selalu menunjukan adanya kematangan dalam berfikir, mampu menentukan keputusan untuk diri sendiri atau keluarganya, seperti keputusan untuk melakukan migrasi kedaerah lain.

Tabel 1. Distribusi kelompok umur migran etnis Jawa di Kota Jambi Tahun 2019

\begin{tabular}{ccc}
\hline Umur & Frekuensi & Persentase \\
\hline $25-34$ & 6 & 12,00 \\
$35-44$ & 20 & 40,00 \\
$45-54$ & 17 & 34,00 \\
$55-64$ & 6 & 12,00 \\
$65-74$ & 1 & 2,00 \\
\hline Jumlah & $\mathbf{5 0}$ & $\mathbf{1 0 0 , 0 0}$ \\
\hline Rata-rata & & $\mathbf{4 4 , 5 6}$ \\
\hline
\end{tabular}

Sumber: Data diolah, 2019

Berdasarkan Tabel 1, menggambarkan bahwa migran etnis Jawa yang terbanyak terletak pada kelompok umur 35 - 44 tahun dengan persentase sebesar 40,00. Hal ini dikarenakan kelompok usia 35 - 44 adalah kelompok usia yang telah memiliki pengalaman dan pemikiran yang telah matang untuk menentukan pilihan mereka sendiri di daerah tujuan migran atau daerah lain. Untuk yang terkecil terletak pada kelompok umur 65 - 74 tahun dengan persentase sebesar 2,00, untuk mereka yang terdapat pada kelompok usia 65 - 74 faktor usia dan produktifitas juga merupakan alasan kenapa kelompok ini sedikit, dan juga pada usia ini individu cenderung ingin kembali ketempat asal. Untuk rata-rata kelompok umur migran etnis Jawa yang menjadi responden adalah 
44,56 atau 45 tahun.

Status Perkawinan

Seseorang cenderung akan mencari pekerjaan yang lebih baik karena adanya status perkawinan, sesorang yang telah menikah tentunya memiliki tanggun jawab yang besar dibandingkan dengan yang belum menikah. Berikut adalah data status perkawinan punduduk migran etnis Jawa yang menjadi responden.

Tabel 2. Distribusi status perkawinan migran etnis Jawa di Kota Jambi Tahun 2019

\begin{tabular}{ccc}
\hline Status Perkawinan & Frekuensi & Persentase (\%) \\
\hline Kawin & 47 & 94,00 \\
Belum Kawin & 3 & 6,00 \\
\hline Total & $\mathbf{5 0}$ & $\mathbf{1 0 0 , 0 0}$ \\
\hline
\end{tabular}

Sumber: Data diolah, 2019

Berdasarkan Tabel 2, menggambarkan sebanyak 50 penduduk etnis Jawa yang menjadi respondent paling banyak mempunyai status perkawinan kawin yaitu sebanyak 47 respondent atau 94,00 \% dan yang mempunyai status perkawinan belum kawin yaitu sebesar $6,00 \%$.

\section{Jumlah Tanggungan}

Jumlah tanggungan keluarga adalah jumlah anggota dalam suatu keluarga yang menjadi beban tanggungan kepala keluarga.

Tabel 3. Distribusi jumlah tanggungan migran etnis Jawa di Kota Jambi Tahun 2019

\begin{tabular}{|c|c|c|}
\hline Jumlah Tanggungan & Frekuensi & Persentasi (\%) \\
\hline $1-2$ & 34 & 68,00 \\
\hline $3-4$ & 13 & 26,00 \\
\hline Total & 50 & 100,00 \\
\hline Rata-rata & & \\
\hline
\end{tabular}

Sumber: Data diolah, 2019

Berdasarkan Tabel 3, dapat dipaparkan jumlah tanggungan responden terbesar ada pada jumlah tanggungan 2 orang, dengan kata lain dalam satu rumah tangga hanya memiliki satu anak, karena istri sudah terhitung 1 tanggungan. Sebagian besar dari mereka yang memiliki jumlah tanggungan sedikit mengaku faktor ekonomi sebagai alasan mereka tidak memiliki banyak anak, ketakutan akan mahalnya biaya pendidikan menjadi penyebab utama, sebagian lagi mereka yang memiliki jumlah tanggungan sedikit dikarekan anak mereka telah banyak menikah hal itu menyebabkan tidak dihitung dalam jumlah tanggungan. Jumlah tanggungan 1 orang dengan persentase sebesar 26,00 mereka yang memiliki 1 tanggungan dapat diartikan mereka hanya hidup dengan istri, ini terjadi pada kelompok umur 55 - 74 dikarenakan anak mereka telah menikah semua. Kemudian jumlah tanggungan 3 orang sebesar 22,00 dan jumlah tanggungan 4 orang dengan persentase sebesar 4,00 .

\section{Pendidikan}

Tingkat pendidikan formal yang pernah ditempuh oleh migran etnis Jawa. Pengelompokan tingkat pendidikan dengan tahun sukses yang berhasil ditempuh penduduk etnis Jawa, mulai dari sekolah dasar, sekolah menengah pertama, sekolah 
menengah atas dan seterusnya. Sementara untuk sekolah- sekolah islam seperti madrasah ibtidaiyah, tsanawiyah dan aliyah akan menyesuaikan dengan sekolahsekolah negeri. Berikut adalah data tingkat pendidikan migran etnis Jawa di Kota Jambi:

Tabel 4. Distribusi tingkat pendidikan migran etnis Jawa di Kota Jambi Tahun 2019

\begin{tabular}{ccc}
\hline Pendidikan & Jumlah & Persentase (\%) \\
\hline SD & 11 & 22,00 \\
SMP & 17 & 34,00 \\
SMA & 22 & 44,00 \\
\hline Jumlah & $\mathbf{5 0}$ & $\mathbf{1 0 0 , 0 0}$
\end{tabular}

Sumber: Data diolah, 2019

Berdasarkan Table 4, menggambarkan tingkat pendidikan penduduk etnis Jawa yang menjadi responden. Jumlah tingkat pendidikan yag berhasil ditempuh terbesar adalah SMA/Sederajat, kemudian disusul dengan SMP/sederajat, dan yang terkecil adalah Sekolah Dasar. Kemudian untuk rata-rata pendidikan yang ditamatkan oleh responden adalah 9,66 atau 10 tahun. Para penduduk migran etnis Jawa pada umumnya menumpuh pendidikan mereka di daerah asal mereka. Tingkat pendidikan menunjukan kematangan berfikir seeorang, mereka yang berpendidikan tinggi akan lebih berani mengambil keputusan untuk melakukan migrasi ke suatu daerah.

\section{Asal Responden}

Darimana responden itu berasal, meskipun mereka adalah migran etnis Jawa tetapi ada juga yang tidak langsung berasal dari Pulau Jawa, banyak sudah etnis Jawa yang lahir diluar Pulau Jawa tetapi mereka masih mengikuti tradisi dan kebudayaan etnis Jawa. Dalam penelitian ini asal migran etnis Jawa dibedakan menjadi 2 (dua), pertama yaitu yang berasal dari Pulau Jawa dan yang berasal dari luar Pulau Jawa. Berikut adalah data migran etnis Jawa menurut asal:

Tabel 5. Distribusi daerah asal migran etnis Jawa di Kota Jambi tahun 2019

\begin{tabular}{ccc}
\hline Asal Responden & Frekuensi & Persentasi (\%) \\
\hline Pulau Jawa & 36 & 72,00 \\
Luar Pulau Jawa & 14 & 28,00 \\
\hline Jumlah & $\mathbf{5 0}$ & $\mathbf{1 0 0 , 0 0}$ \\
\hline
\end{tabular}

Sumber: Data diolah, 2019

Berdasarkan Table 5, dapat dilihat responden lebih dominan berasal langsung dari Pulau Jawa dengan persentase sebesar 72,00, dimana sebanyak 19 respondent berasal dari Provinsi Jawa Timur, 16 respondent berasal dari Provinsi Jawa Tengah. Hal ini juga tidak dipungkiri dikarenakan Pulau Jawa adalah Pulau di Indonesia yang paling padat penduduk, hal itu juga yang menyebabkan seseorang memutuskan untuk melakukan migrasi, dan yang berasal dari luar Pulau Jawa sebesar 28,00 tersebar dari berbagai Provinsi di Pulau Sumatera, seperti Provinsi Lampung sebanyak 8 respondent, Provinsi Sumatera Selatan sebanyak 5 respondent dan 1 respondent berasasal dari Provinsi Bengkulu. 


\section{Pengetahuan tentang Kota Jambi}

Pada dasarnya seseorang yang akan melakukan migrasi sudah mengerti/tahu tentang daerah tujuan mereka, dimana tempat tujuan yang akan mereka tuju nantinya dapat memberikan apa yang mereka harapkan, biasanya meraka akan mencari tempat bernaung terlebih dahulu. Berikut adalah data tentang pengetahuan migran etnis Jawa tentang Kota jambi yang menjadi tujuan mereka bermigrasi:

Tabel 6. Distribusi migran etnis Jawa berdasarkan pengetahuan tentang Kota Jambi Tahun 2019

\begin{tabular}{ccc}
\hline Mengetahui Kota Jambi & Frekuensi & Persentase (\%) \\
\hline Dari Keluarga & 39 & 78,00 \\
Mencari Informasi Sendiri & 11 & 22,00 \\
\hline Jumlah & $\mathbf{5 0}$ & $\mathbf{1 0 0 , 0 0}$ \\
\hline
\end{tabular}

Sumber: Data diolah, 2019

Berdasarkan Tabel 6 tersebut, dapat dilihat, kebanyakan para responden mengetahui Kota Jambi dari keluarga mereka yang telah terlebih dahulu tinggal di Kota Jambi, sebanyak 39 responden dari total 50 respondent menjawab mengetahui Kota Jambi dari keluarga mereka dengan persentase 78,00 dan 11 responden mengetahui Kota Jambi dengan cara mencari informasi sendiri, dan tidak ada satupun para responden yang menjawab mengetahui Kota Jambi dari sosial media.

\section{Alasan Pindah ke Kota Jambi}

Pertanyaan ini di ajukan kepada responden untuk mengetahui alasan mereka bermigrasi ke Kota Jambi. Pertanyaan dalam poin ini menggunakan pertanyaan pilihan, dimana ada 6 (enam) poin pernyataan dan setiap angka mewakili pernyataan sebagai berikut: 1) Lapangan pekerjaan yang lebih menjanjikan; 2) Upah/gaji yang lebih besar; 3) Keinginan sendiri; 4) Pernikahan; 5) Diajak oleh saudara/teman; 6) Dinas. Berikut adalah data alasan penduduk etnis Jawa pindah ke Kota Jambi:

Tabel 7. Distribusi alasan pindah migran etnis jawa di Kota Jambi Tahun 2019

\begin{tabular}{lcc}
\hline Alasan Pindah ke Kota Jambi & Frekuensi & Persentase (\%) \\
\hline Lapangan pekerjaan yang lebih menjanjikan & 8 & 16,00 \\
Upah/ gaji yang lebih besar & 8 & 16,00 \\
Keinginan sendiri & 19 & 38,00 \\
Pernikahan & 1 & 2,00 \\
Diajak oleh saudara/ teman & 14 & 28,00 \\
\hline Jumlah & $\mathbf{5 0}$ & $\mathbf{1 0 0 , 0 0}$ \\
\hline
\end{tabular}

Sumber: Data diolah, 2019

Berdasarkan Tabel 7, menjelaskan alasan para penduduk etnis Jawa untuk pindah ke Kota Jambi, dari tabel tersebut dapat dilihat alasan para penduduk etnis Jawa pindah ke Kota Jambi yang paling tinggi adalah keinginan sendiri, sebanyak 19 responden menjawab keinginan sendiri untuk alasan mereka pindah ke Kota Jambi dengan persentase sebesar 38,00, keputusan untuk melakukan migrasi adalah suatu keputusan individu, membuat keinginan sendiri menjadi urutan pertama sebagai alsan mereka bermigrasi. Disusul dengan alasan diajak saudara/teman dengan persentase 28,0. Kemudian alasan lapangan pekerjaan yang lebih menjanjikan dan upah/gaji yang lebih 
tinggi, masing-masing memiliki persentase yang sama yaitu 16,0. Alasan pernikahan hanya 1 (satu) responden yang menjawab alasan tersebut, dan tidak ada yang menjawab untuk alasan dinas.

\section{Lama Tinggal}

Lama tinggal disini adalah sudah berapa lama penduduk etnis Jawa tersebut sudah menetap di Kota Jambi, terhitung dari pertama kali mereka datang ke Kota Jambi. Lama tinggal disini dihitung dengan ukuran tahun, dengan menggunakan rumus statistik untuk menentukan data kelompok lama tinggal:

Tabel 8. Distribusi lama tinggal migran etnis Jawa di Kota Jambi Tahun 2019

\begin{tabular}{ccc}
\hline Lama Tinggal (Tahun) & Frekuensi & Persentase \\
\hline $5-15$ & 42 & 84,00 \\
$16-30$ & 6 & 12,00 \\
$31-55$ & 2 & 4,00 \\
\hline Jumlah & $\mathbf{5 0}$ & $\mathbf{1 0 0 , 0 0}$ \\
\hline Rata-rata & & $\mathbf{1 3 , 7}$ \\
\hline
\end{tabular}

Sumber: Data diolah, 2019

Berdasarkan Tabel 8, dapat di jelaskan penduduk etnis Jawa di Kota Jambi ratarata telah tinggal di Kota Jambi selama 13,70 atau 14 tahun. Paling banyak penduduk etnis Jawa telah tinggal di Kota Jambi terdapat pada kelompok 5-15 tahun, dimana sebanyak 17 respondent mengaku telah tinggal di Kota Jambi selama 10 tahun, kemudian kelompok 16-30 tahun sebesar 12,00, dan yang paling lama yaitu antara $31>$ tahun, hanya terdapat 2 respondent yang telah lama menetap di Kota Jambi, yang pertama yaitu telah tinggal di Kota Jambi selama 35 tahun dan yang kedua selama 54 tahun telah tinggal di Kota Jambi, mereka bermigrasi ke Kota Jambi mengikuti program pemerintah dan semenjak saat itu mereka menetap di Kota Jambi.

\section{Pekerjaan}

Pekerjaan merupakan faktor penting bagi keberlangsungan keputusan bagi penduduk etnis Jawa di Kota Jambi, mendapatkan pekerjaan tentu akan sangat diharapkan didaerah tujuan, jika tidak endapatkan pekerjaan itu bisa membuat mereka bermigrasi ketempat lain. Dengan menggunakan rumus statistik untuk menentukan kelompok pekerjaan para penduduk migran etnis Jawa, berikut adalah data pekerjaan penduduk migran etnis Jawa yang ada di Kota Jambi:

Tabel 9. Distribusi pekerjaan migran etnis Jawa di Kota Jambi Tahun 2019

\begin{tabular}{lcc}
\hline Pekerjaan & Frekuensi & Persentase \\
\hline Berusaha Sendiri & 3 & 6,00 \\
Pedagang & 14 & 28,00 \\
Buruh/Kariawan Swasta/Pegawai & 31 & 62,00 \\
Pegawai Bebas di Pertanian & 2 & 4,00 \\
\hline Jumlah & $\mathbf{5 0}$ & $\mathbf{1 0 0 , 0 0}$ \\
\hline
\end{tabular}

Sumber: Data diolah, 2019

Berdasarkan Tabel 9, pekerjaan penduduk migran etnis Jawa yang ada di Kota Jambi paling dominan ialah Buruh/Kariawan swasta/Pegawai dengan persentase sebesar 62,00 , dimana dalam kelompok klasifikasi pekerjaan ini terbagi-bagi yaitu buruh tidak 
tetap sebanyak 6 respondent, buruh tetap sebanyak 8 respondent, karyawan swasta 16 responden, dan pegawai honorer 1 respondent. yang dimaksud kariawan swasti disini adalah mereka yang bekerja di suatu perusahaan. Pedagang menjadi urutan kedua pekerjaan para migran yaitu sebesar 28,00 , para penduduk migran etnis Jawa disini sebagian besar berdagang sayur-sayuran dipasar Angso Duo dan ruko-ruko didekat rumah mereka. kemudian pekerja buruh tidak tetap, yang dimaksud buruh tidak tetap disini adalah mereka yang memiliki pekerjaan tidak tetap, mungkin dalam satu minggu mereka bisa mempunyai 2 - 4 pekerjaan atau bahkan tidak sama sekali. Sedangkan buruh tetap adalah mereka tidak memiliki pekerjaan maka mereka akan bertani dan yang paling sedikit adalah pegawai honerer, hanya 1 penduduk migran etnis Jawa yang bekerja sebagai pegawai honorer.

\section{Pendapatan}

Pendapatan merupakan salah satu indikator ekonomi yang paling menetukan baik tidaknya kondisi sosial ekonomi seseorang (Andri Pratama, 2018). Bisa dikatakan jika semakin tinggi pendapatan mereka maka semakin tinggi pula kesejahteraan yang dapat dicapai oleh individu, jika tingkat kesejahteraan itu dapat dicapai, besar kemungkinan itu akan membuat keputusan mereka untuk menetap di daerah tujuan, seperti yang telah dipaparkan dalam pendahuluan sebelumnya, motiv seseorang melakukan migrasi adlah ekonoomi, alat ukur ekonomi seseorang yaitu dengan pendapatan mereka.

Pendapatan yang dihitung dalam penelitian ini adalah pendapatan kotor selama satu bulan dari para penduduk migran etnis Jawa. Dengan menggunakan rumus statistik untuk menentukan data pendapatan responden, berikut adalah data responden berdasarkan pendapatan:

Tabel 10. Distribusi pendapatan migran etnis Jawa di Kota Jambi Tahun 2019

\begin{tabular}{|c|c|c|}
\hline Pendapatan Perbulan (Rp) & Frekuensi & Persentase $(\%)$ \\
\hline $2.000 .000-2.500 .000$ & 3 & 6,00 \\
\hline $2.500 .001-3.000 .000$ & 13 & 26,00 \\
\hline $3.000 .001-3.500 .000$ & 21 & 42,00 \\
\hline $3.500 .001-4.000 .000$ & 13 & 26,00 \\
\hline Jumlah & 50 & 100,00 \\
\hline Rata-rata & \multicolumn{2}{|c|}{3.366 .000} \\
\hline
\end{tabular}

Sumber: Data diolah, 2019

Berdasarkan Tabel 10, dapat menjelaskan pendapatan para migran etnis Jawa paling dominan adalah pada besaran Rp. 3.50.000 - Rp. 3.500.000 dengan persentase sebesar 42,00, pada kelompok pendapatan tersebut banyak penduduk etnis Jawa yang telah lama tinggal di Kota Jambi, oleh karena itu mereka telah memiliki investasi berupa kebun, dan lahan untuk mereka bertani. Kemudian diikuti oleh pendapatan Rp. 2.550.000 - Rp. 3.000.000 dengan persentase sebesar 26,00, mereka yang terdapat dalam kelompok ini adalah penduduk etnis Jawa yang bekerja di sektor pertanian dan mereka yang berjualan/ pedagang. Kemudian untuk persentase paling rendah yaitu 6,00 dengan pendapatan dengan kisaran Rp. 2.000.000 - Rp. 2.500.000. Untuk rata-rata pendapatan para responden adalah Rp. 3.336 .000 perbulan, angka ini diatas UMK Kota 
jambi tahun 2018 yaitu sebesar Rp. 2.381.941, bisa dikatakan penduduk etnis Jawa di Kota Jambi telah mendapatkan apa yang mereka inginkan, dimana keinginan untuk menetap akan semakin besar.

\section{HASIL DAN PEMBAHASAN}

\section{Hasil Analisis Regresi Linier Berganda}

Guna mengetahui pengaruh variabel independen (X) dengan variabel dependent (Y) yang dalam penelitian ini variabel independen umur (U), asal (Da), tingkat pendidikan $(\mathrm{P})$ dan lama tinggal $(\mathrm{Lt})$ terhadap variabel dependen pendapatan $(\mathrm{P})$ digunakan analisis kuantitatif dengan model regresi linier berganda. Hasil estimasi model regresi linier berganda sebagai berikut:

Tabel 11. Hasil analisis regresi linier berganda

\section{Coefficients $^{\mathrm{a}}$}

\begin{tabular}{|c|c|c|c|c|c|c|}
\hline \multirow{2}{*}{ Model } & \multicolumn{2}{|c|}{ Unstandardized Coefficients } & \multicolumn{4}{|c|}{$\begin{array}{l}\text { Standardized } \\
\text { Coefficients }\end{array}$} \\
\hline & $\mathbf{B}$ & Std. Error & Beta & & $\mathbf{t}$ & Sig. \\
\hline (Constant) & 1355065,597 & 330877,583 & & & 4.095 & .000 \\
\hline Umur & 25218,868 & 9453,875 & & .327 & 2.668 & .011 \\
\hline $\mathrm{Da}$ & 206993,847 & 141235,228 & & .130 & 1.466 & .150 \\
\hline Lamatinggal & 38719,316 & 10921,799 & & .415 & 3.545 & .001 \\
\hline Pdk1 & 654586,436 & 175020,879 & & .433 & 3.740 & .001 \\
\hline Pdk2 & 807409,348 & 175868,308 & & .559 & 4.591 & .000 \\
\hline
\end{tabular}

Sumber: Data diolah, 2019

Berdasarkan Tabel 11, diketahui hasil estimasi regresi linier berganda menunjukan nilai koefisien umur sebesar 25218,868 bertanda positif. Hal ini menunjukan ketika umur migran bertambah 1 tahun, maka pendapatan para migran akan bertambah sebesar Rp. 25.218,868 dengan asumsi A, Pd, dan Lm konstan. Bertambahnya umur maka akan menambah pendapatan para migran, seperti diketahui umur terkadang menjadi patokan untuk bekerja, semakin tinggi umur seseorang maka ia meminta penghasilan yang lebih tinggi pula, dengan pengalaman dan ilmu yang ia miliki.

Dari hasil estimasi regresi linier berganda menunjukan bahwa variabel asal dengan tingkat signifikansi $0,05 \%$ tidak berpengaruh signifikan terhadap pendapatan penduduk migran etnis jawa. Jadi bisa dikatakan asal tidak mempengaruhi pendapatan dikarenakan jika penduduk etnis jawa itu mau bekerja apapun tak peduli dari mana mereka berasal, mereka akan mendapatkan pendapatan.

Nilai koefisien Dummy pendidikan SLTP (Pdk1) sebesar 654.586,436 bertanda positif. Dapat dikatakan jika penduduk migran entis Jawa tersebut berpendidikan SLTP maka pendapatan mereka akan lebih besar Rp. 654.586,436 dibandingkan penduduk migran yang berpendidikan SD.

Nilai koefisien Dummy pendidikan SLTA (Pdk2) sebesar 807.409,348 bertanda positif. Ini berarti jika para migran berpendidikan SLTA maka pendapatan mereka lebih besar Rp. 807.409,348 dibandingkan migran yang berpendidikan SD dengan asumsi U, A, dan Lt konstan. Disini berarti semakin tinggi pendidikan yang ditamatkan maka semakin tinggi pendapatan yang diperoleh, dikarekan pendidikan menjadi salah satu 
tolak ukur dalam beberapa pekerjaan.

Nilai koefisien lama tinggal (Lm) sebesar 38.719,316 bertanda positif. Ini berarti semakin lama mereka tinggal di Kota Jambi maka semakin besar pula pendapatan yang mereka terima, dikarenakan semakin lama mereka menetap maka semakin banyak pengalaman, dan mungkin mereka telah memiliki investasi seperti membeli lahan, membuka lahan pertanian sendiri, maka pedapatan merekapun akan bertambah. Nilai koefisien untuk variabel lama tinggal sebesar 38719,316 dengan demikan setiap terjadi peningkatan lama tinggal selama 1 tahun, maka pendapatan para migran etnis Jawa akan bertambah sebesar Rp. 38.719,316 dengan asumsi U,A, dan Pd konstan.

\section{Uji Hipotesis Secara Simultan (Uji F)}

Uji F digunakan untuk mengetahui apakah variabel-variabel independent secara simultan berpengaruh signifikan terhadap variabel dependent. Derajat kepercayaan yang digunakan adalah 0,05. Pengujian ini dilakukan dengan membandingkan nilai signifikansi pada tabel ANOVA dengan nilai $\alpha$ yaitu 0,05 . Apabila nilai signifikansi pada tabel lebih kecil dari nilai $\alpha(0,05)$, maka hipotesis alternatif yang menyatakan bahwa semua variabel independent secara simultan berpengaruh signifikan terhadap variabel dependent diterima.

Tabel 12. Uji F

ANOVA $^{\text {b }}$

\begin{tabular}{lccccc}
\hline Model & Sum of Squares & df & Mean Square & F & Sig. \\
\hline Regression & $1,77 \mathrm{E}+16$ & 5 & $3,54 \mathrm{E}+15$ & 19.477 & $.000^{\mathrm{a}}$ \\
Residual & $7,99 \mathrm{E}+15$ & 44 & $1,82 \mathrm{E}+14$ & & \\
Total & $2,57 \mathrm{E}+16$ & 49 & & & \\
\hline
\end{tabular}

Sumber : Data diolah, 2019

Berdasarkan Tabel 12, nilai signifikansi menunjukan angka 0,000 dan nilai $\alpha$ yang digunakan dalam penelitian ini adalah 0,05 sedangkan nilah $F_{\text {hitung }}$ pada tabel di atas adalah 19.477. Jadi dapat dikatakan variabel independent secara simultan berpengaruh signifikan terhadap variabel dependent, dikarenakan nilai sig. $(0,000)<\alpha$ $(0,05)$ yang berarti $\mathrm{H}_{0}$ ditolak yang berarti ada pengaruh (signifikan). Hal ini menunjukan bahwa secara brsama-sama umur, asal, tingkat pendidikan, dan lama tinggal berpengaruh nyata terhadap pendapatan penduduk migran etnis Jawa.

\section{Koefisien Determinan $\left(\mathbf{R}^{2}\right)$}

Melalui koefisien determinasi(Adjusted $R$ Square) dapat diketahui sejauh mana variabel umur, asal, tingkat pendidikan, dan lama tinggal mampu mempengaruhi pendapatan penduduk migran etnis Jawa. Nilai koefisien ini antara 0 dan 1, jika hasil lebih mendekati 0 berarti kemampuan variabel-variabel independent dalam menjelaskan variabel dependent amat terbatas. Tapi jika hasil mendekati angka 1 berarti variabelvariabel independent memberikan hampir semua informasi yang dibutuhkan untuk memprediksi variasi variabel dependent.

Tabel 13. Koefisien determinan $\left(\mathrm{R}^{2}\right)$

\section{Model summary}

\begin{tabular}{llllc}
\hline Model & R & R Square & Adjusted R Square & Std. Error of the Estimate \\
\hline 1 & $.830^{\mathrm{a}}$ & .689 & .653 & 426.018 .166 \\
\hline
\end{tabular}




\section{Sumber : Data diolah, 2019}

Dari Tabel 13, nilai Adjusted $R$ Square sebesar 0,653 menunjukan bahwa besaran pengaruh variabel independen umur (U), asal (A), pendidikan (Pd), dan lama tinggal (Lm) terhadap variabel dependent pendapatan para migran sebesar $65,30 \%$ sedangkan 34,70\% dipengaruhi atau dijelaskan oleh varibel lain yang tidak dimasukan dalam penelitian ini. karena nilai Adjusted $R$ Square diatas 50,00\% maka dapat disimpulkan kemampuan variabel-variabel independent mampu menjelaskan variasi variabel dependent.

\section{Uji Hipotesis Secara Parsial (Uji T)}

Pengujian secara persial atau uji t dimaksudkan untuk mengetahui apakah variabel-variabel independent secara sendiri-sendiri berpengaruh nyata atau tidak terhadap variabel dependent. Derajat signifikansi yang digunakan adalah 0,05. Apabila nilai signifikansi lebih kecil dari derajat kepercayaan maka kita menerima hipotesisi alternatif, yang menyatakan bahwa suatu variabel independent secara parsial mempengaruhi variabel dependent. Dalam penelitian ini menggunakan uji tingkat keyakinan 95\% $(\alpha=0,05 \%)$ dimana variabel independent dikatakan berpengaruh apabila nilah sinifikansi dari hasil estimasi lebih kecil dari nilai $\alpha$ yaitu 0,05 .

\section{Uji t untuk umur (U)}

Dari hasil estimasi model regresi diketahui nilai signifikansi varibel umur sebesar 0,011 sementara nilai $\alpha$ 0,05. Dengan demikan dapat dinyatakan bahwa Sig. $(0,011)<\alpha(0,05)$ maka $\mathrm{H}_{0}$ diterima yang artinya umur berpengaruh signifikan terhadap pendapatan penduduk migran etnis Jawa.

\section{Uji t untuk asal (Da)}

Dari hasil estimasi model regresi diketahui nilai signifikansi varibel asal sebesar 0,150 sementara nilai $\alpha 0,05$. Dengan demikan dapat dinyatakan bahwa Sig. $(0.150)>\alpha$ $(0,05)$ maka $\mathrm{H}_{0}$ ditolak yang artinya asal tidak berpengaruh signifikan terhadap pendapatan penduduk migran etnis Jawa.

\section{Uji t untuk dummy pendidikan SLTP (Pdk1)}

Dari hasil estimasi model regresi diketahui nilai signifikansi varibel dummy untuk pendidikan SLTP sebesar 0,001 sementara nilai $\alpha$ 0,05.. Dengan demikan dapat dinyatakan bahwa Sig. $(0,001)>\alpha(0,05)$ maka $\mathrm{H}_{0}$ diterima yang artinya dummy pendidikan SLTP berpengaruh signifikan terhadap pendapatan penduduk migran etnis Jawa.

\section{Uji t untuk dummy pendidikan SLTA (Pdk2)}

Dari hasil estimasi model regresi diketahui nilai signifikansi varibel dummy untuk pendidikan SLTA sebesar 0,000 sementara nilai $\alpha 0,05$. Dengan demikan dapat dinyatakan bahwa Sig. $(0,000)>\alpha(0,05)$ maka $\mathrm{H}_{0}$ diterima yang artinya dummy pendidikan SLTA berpengaruh signifikan terhadap pendapatan penduduk migran etnis Jawa.

\section{Uji t untuk lama tinggal (Lm)}

Dari hasil estimasi model regresi diketahui nilai signifikansi varibel lama tinggal sebesar 0,001 sementara nilai $\alpha$ 0,05. Dengan demikan dapat dinyatakan bahwa Sig. $(0,001)<\alpha(0,05)$ maka $\mathrm{H}_{0}$ diterima yang artinya lama tinggal berpengaruh signifikan terhadap pendapatan penduduk migran etnis Jawa. 


\section{KESIMPULAN DAN SARAN}

\section{Kesimpulan}

Berdasarkan hasil dan pembahasan sebelumnya dapat ditarik beberapa kesimpulan penelitian sebagai berikut:

Penduduk migran etnis Jawa di Kota Jambi memiliki berumur rata-rata 44 tahun. Status perkawaninan terbanyak yaitu menikah. Rata-rata jumlah tanggungan adalah 2 orang. Menurut pendidikan, sebagian besar berpendidikan SMA dengan pesentase 34,00 dengan rata-rata tahun sukses pendidikan yang berhasil ditempuh 10 tahun. Dari asal tempat tinggal sebelum masuk ke Kota Jambi 72,00 responden berasal dari Pulau Jawa, dan alasan pindah ke Kota Jambi sebanyak 39,00 dengan alasan keinginan sendiri dan mengetahui Kota Jambi dari anggota keluarga sebesar 78,00. Menurut lama tinggal ratarata penduduk etnis Jawa telah tinggal di Kota Jambi selama 14 tahun. Untuk pekerjaan, penduduk etnis Jawa yang ada di Kota Jambi paling banyak bekerja sebagai Karyawan Swasta dengan persentase $32 \%$, dan untuk pendapatan penduduk etnis Jawa di Kota Jambi yang menjadi responden memperoleh pendapatan rata-rata Rp. 3.336 .000 per bulan.

Dilihat dari hasil regresi berganda, dapat disimpulkan bahwa variabel umur, tingkat pendidikan dan lama tinggal berpengaruh signifikan terhadap pendapatan para penduduk etnis Jawa di Kota Jambi, sedangkan variabel asal tidak berpengarruh terhadap pendapatan para penduduk migran etnis Jawa di Kota Jambi. Kemudian melalui uji hipotesis secara simultan yaitu uji $\mathrm{F}$ didapatkan nilai $\mathrm{F}_{\text {hitung }} 19,477$ dan nilai signifikansi sebesar 0,000 dengan begitu dapat dikatakan variabel independent secara bersama-sama (simultan) berpengaruh terhadap variabel dependent. Untuk uji t yaitu untuk melihat pengaruh masing-masing variabel independet terhadap variabel dependent dengan derajat kepercayaan yang digunakan adalah $95 \%$ dan nilai alfa $(\alpha=$ 0,05). Dimana nilai signifikansi dari masing - masing variabel tersebut lebih kecil dari nilai alfa $(\alpha)$, dimana variabel umur memiliki nilai signifikansi sebesar 0,011 sementara variabel lama tinggal seberas 0,001 dan variabel tingkat pendidikan SMP sebesar 0,001 dan tingkat pendidikan SMA sebesar 0,000. Untuk melihat besaran pengaruh variabel independent terhadap variabel dependent dapat dilihat pada nilai Adjusted $R$ Square, dalam penelitian ini nilai Adjusted $R$ Square adalah 0,653 itu berarti besaran pengaruh variabel independent terhadap variabel dependent sebesar $65,30 \%$ sedangankan $34,70 \%$ lainya dipengaruhi oleh variabel lain yang tidak dimasukkan dalam penelitian ini.

\section{Saran}

Diharapkan para penduduk migran etnis Jawa yang berada di Kota Jambi untuk menambah tingkat pendidikan mereka supaya bisa menaikan jumlah pendapatan yang didapat.

Diharapkan para penduduk migran etnis Jawa juga mematangkan tingkat umur mereka sebulum melakukan migrasi, dikarenakan dalam penelitian ini tingkat umur berpengaruh terhadap pendapatan yang diterima para penduduk ,igran etnis Jawa di Kota Jambi.

Kemudian untuk lama tinggal diharapkan para penduduk migran etnis Jawa di Kota Jambi untuk lebih lama tinggal di Kota Jambi, supaya dapat menaikkan pendapatan yang diperoleh.

\section{DAFTAR PUSTAKA}

Amir Amri, Junaidi dan Yulmardi. (2009). Metodologi Penelitian Ekonomi dan Penerapannya. IPB Pers: Bandung.

Badan Pusat Statistik. (2010). Penduduk Provinsi Jambi (SP 2010). BPS Provinsi Jambi: Jambi. 
Badan Pusat Statistik. (2015). Laju Pertumbuhan Ekonomi menurut Kab/Kota Tahun 2004 - 2015. BPS Provinsi Jambi: Jambi.

Badan Pusat Statistik. (2016). Data migrasi kabupaten/kota Provinsi Jambi tahun 20042010. BPS Provinsi Jambi: Jambi.

Badan Pusat Statistik. (2018). Kota Jambi Dalam Angka 2018. BPS Provinsi Jambi: Jambi.

Lee Everett S. (1992). Teori Migrasi. Pusat Penelitian Kependudukan Universitas Gadjah Mada: Yogyakarta.

Munir Rozi. (2000). Dasar-dasar Demografi. 2000. Lembaga Penerbit UI: Jakarta.

Septiani Venti. (2015). Faktor-Faktor Yang Mempengaruhi Migrasi Risen Masuk di Kabupaten/Kota Provinsi Jambi. Skripsi. Fakultas Ekonomi Dan Bisnis Universitas Jambi: Jambi.

Suharyadi dan Purwanto. (2011). Statistika untuk Ekonomi dan Keuangan Modern Edisi 2. Salemba Empat: Jakarta.

Pratama Andri. (2018). Analisis Kondisi Sosial Ekonomi Pekerja Sektor Informal (studi kasus pedagang kaki lima yang berada di lingkungan kampus Pinang Masak Universitas Jambi). Skripsi. Fakultas Ekonomi dan Bisnis Universitas Jambi: Jambi. 